\title{
The Disappearance of American Dream in the Consumerism Age from the Perspective of Network
}

\author{
Xuenong Xiao, Chunmei Song
}

Jiangxi Institute of Economic Administrators, Nanchang, Jiangxi, 330088

Keywords: Disappearance of American Dream, Consumerism Age, the Perspective of Network

\begin{abstract}
With the continuous development of network technology, through trade, foreign investment, capital investment will be the integration of various countries into a whole economy. American dream as one of the world's most influential dreams, the main thing is that people through their own unremitting efforts, you can live a better life in the United States. The realization of the American dream in the United States at all times to maintain the development of the "civilians to the rich" spirit of the pursuit, which is the focus of American culture and spiritual performance. In the era of high-speed development of the Internet, the correct view of the US era of consumer dreams of the burst, from the burst of American dream to learn some lessons for China to achieve the Chinese dream has extraordinary significance.
\end{abstract}

\section{Introduction}

American dream has been accompanied by the development of the United States, its core content to personal struggle, and actively develop their own ability and to achieve their own rich and powerful. But with the continuous development of network technology, capital began to spread the scope of the world, expanding the company cannot be efficient gathering of capital throughout the country. In the context of global consumption, capital flows to the world, every Wall Street investor began to seek cross-border cooperation, making the US capital "bubble" phenomenon, making a large number of local workers lost their jobs, houses, capital, making the American dream began Shattered. Through the understanding of the content and origin of the United States, this article analyzes the values of American dream, and finally analyzes the American dream from the network perspective, hoping that China will take the initiative and develop the Chinese dream of Chinese society reasonably.

\section{The American Dream Changes at Different Times}

The Early American Dream. In the early days, the American dream could be the ideal of American development, with the goal of establishing a "democratic, free and equal" state. In 1606, the British King franchise more than 100 British entrepreneurs came to the eastern United States, and the establishment of the first British colonial state, poor ecological environment and the environment so that the British germination to the United States "New World" the pursuit of freedom, the earliest "American Dream" is the pursuit of freedom of Puritan believers developed. At that time, the growing demands for the formation of the anti-bourgeoisie by the increasingly powerful Puritan forces eventually overturned the British notification in the United States and established a country seeking religious freedom. In the eastern United States, they established a 
democratic society that advocated freedom, and everyone thought that "only God was absolutely free." They worked hard and self-discipline to influence God to build a heavenly kingdom. This is also the early American and they are brave, tenacious, and firmly believe that they can build a democratic, free, prosperous country.

At that time, the United States had not yet developed, but with vast land, rich resources, coupled with the then Puritan theory to help the entire eastern region of the economy has been rapid development, to the US immigrants have a stable life, completely changed the spirit of the restraint in the past. And the Americans at that time have a strong pioneering spirit, through the pioneers and they enjoy the development of local economy, culture and policy. The leader is aware that people enjoy the right to restore their freedom and establish a system to protect their freedom. Later, Rousseau stressed that legislative power should belong to the people, and can only belong to the people.

The "American Dream" under the Economic Era. American dream in the post-industrial era, the ultimate goal of development: "Every American people have a higher education, have a high social status, happy life, healthy body, lovely children, two cars, independent homes", such a US Dream is too dreamy, but also from the side reflects the expansion of the United States material.

The United States as a new capitalist country, its industrial output and railway network in 1880 has accounted for the first in the world, this time, the socio-economic began to transition, the influx of agricultural workers into the city, commercial agriculture began to appear, a large number of the immigrants brought to it is the issue of social order. At that time, the city frequently violent, drug and other cases, until the 20th century, the US social security was well managed, while the US economy has also been a very good development. At the beginning of the twentieth century, there have been scenarios described in the American dream, men can make money to support their families, women at home care, as well as a few lovely children, children are studying in private schools. At this point there is a credit card casually brush, private yachts, aircraft purchase needs to increase a series of expansion of personal consumption, "American Dream" began to continue to burst until the burst.

\section{The Values of the United States Dream at the Consumer Era}

Consumer culture is the product of modern industrial development in the United States, its basic characteristics is the luxury consumption, the pursuit of money and property of the greed, these consumer ideas tend to bring daily life "ethics", "social consumption unfair" phenomenon. In such a consumer concept, people spend is not love can help life needs, but to meet their growing consumer view.

Related scholars will be divided into three levels of consumption, leisure consumption, to show off consumption and standardized consumption, leisure consumption is a material to enjoy the main, so that consumption makes people greedy. The second is to show off consumption, show off consumption is to meet people's vanity, will cause comparisons, follow the trend, slander and other phenomena standardized consumption is the people of their own needs reasonable consumption. But Americans in the consumer age are almost addicted to enjoying material life and are keen to show off their wealth and status.

After the First World War, the United States as a victorious country its economy has never been an unprecedented development of material goods for the later excessive consumption provides the basis for large-scale production for the US economic development to provide help. The rapid development of the economy made people began to blindly worship the wealth, so that people at the time of the traditional concept and even religious beliefs have changed, the new faith was born, 
people began to pursue their eyes the so-called "American dream."

The original idea of the American dream is freedom, but in the consumer age, the idea of the American dream becomes "no matter what your origin is, you can be through their own efforts and their ability to cultivate and succeed, and then the so-called Success is, to maximize the material and premenstrual collection. Therefore we can see the role of finance in the consumer era, "American Dream" has become the essence of the pursuit of financial frenzy, so that the pursuit can be reckless, and even do not fold means that this consumerism gradually corrode the American youth personality, thinking, long before they are extremely eager for money and rights, and finally led to the destruction of the American dream.

American dream of worshiping wealth, want to have money, have status, and then enjoy life, which would have nothing wrong with it. But the development to the end, the Americans have to chase money, and even that the money is a panacea. The values of American dreams make people concerned only with the results and the so-called "values", which lead people to ignore the value and meaning of human existence. Dewey criticized the current state of US consumption, emphasizing: "If there is no thought to participate, enjoy it will not have value, only when you enjoy a change in our wisdom in the event of re-generation, it has value" Dewey said that Americans should reflect on their own situation. Unrestrained material attention to people's lives have a huge impact, this moral perspective and there should be a normal values.

\section{The Rational Thinking of the American Dream Burst in the Network Perspective}

The dream of pursuing democracy, freedom and equality is the ultimate goal of any social development. From the experience of American dream development, the bustling capital has compiled a huge dream bubble for the Americans. With the US oil prices soaring, Lehman Brothers business down, AIG financial company's collapse, the American dream also will be shattered.

Throughout the development of the American dream, we can clearly see that the American dream from the beginning of the pursuit of freedom gradually become the pursuit of capital, American pragmatism will be the value of their own personal judgments have been established in the wealth, status And the pursuit of rights, each component of society are interdependent, and most of the population of most of the migration, will bring instability to the community interference.

With the continuous development of network technology, our nationals received foreign economic and cultural influence, there have been some people, blindly worship the Western culture of individualism. Chinese relevant departments should effectively prevent the Western countries values, interests of the invasion to promote Chinese cultural network construction, improve the relevant network education mechanism.

With the gradual development of e-commerce, people meet the food and clothing, began to show off their wealth, comparisons of the atmosphere. Such consumer attitudes need to attract the attention of the relevant departments, because such consumption habits not only make their own income make ends meet, but also affect the people around, driving people around the vicious consumption. To this end, Chinese relevant departments should guide the people to the correct view of consumption to help the country rational development.

Through personal development, efforts to obtain the appropriate development are desirable, and Chinese relevant departments should promote the competitive reward system. Encourage the development of individual potential, the implementation of entrepreneurial wealth initiatives. At the same time to encourage students should have the courage to bear social responsibility, to prevent people and people, the development of the relationship between man and nature against the accident to provide the corresponding social and cultural concerns. While strengthening the security of the 
network construction, and now the network of violent games, obscene publications will have a certain impact on social stability.

The first revelation is that we should start from the happiness of the individual, everyone has the right to chase the dream, the dream of each person together, together with the dream of the United States, the United States dream of the realization of the dream, no doubt has a certain reference and inspiration. We should learn from the American dream of respect for individual dreams, everyone has a dream, only full respect can gather all the dreams. The second revelation is that we advocate individual struggle at the same time, but also the importance of harmonious development of social braking, cannot blindly pursue personal interests. The realization of dreams requires personal hard work, but also a fair and just environment, which has a fair and just environment to promote their own good development.

\section{Conclusion}

To sum up, the origin of the American dream is to seek the "fair, democratic, free" legal society, but in the rapid economic development, slowly transformed into the extreme desire for wealth, and finally lead to excessive consumption of US citizens the American dream was finally broken. In the era of the Internet, the social and economic globalization, the Western economic model and culture gradually affect the thinking of the domestic masses, but also the phenomenon of high consumption, for which China should strictly control to effectively control the impact of Western culture on our young people's consumer attitudes.

\section{Acknowledgements}

Fund Project: Jiangxi Province Colleges and Universities Humanities and Social Sciences Research "The Disillusion of American Dream in the Age of Consumerism - On Arthur Miller's Death of a Salesman."

Reference Fund Project: Jiangxi Province Colleges and Universities Humanities and Social Sciences Research “The Disillusion of American Dream in the Age of Consumerism - On Arthur Miller's Death of a Salesman.”(WGW1506) s

[1] $\mathrm{Yu}$ Xiaochuan. The Hypocrisy of the American Dream and Its Essence - The Marxist Interpretation of "The Great Gatsby"[J]. Journal of Yibin University, 2009, 02: 38-40.

[2] Jiang Yong. Financial capitalism is exhausting all the reasons for its existence - from the "occupation of Wall Street" demonstrations [J]. Red Flag, 2011, 20: 4-9.

[3] Jiang Yong. Financial capitalism is exhausting all the reasons for its existence - from the "occupation of Wall Street" demonstrations [J]. Theoretical reference, 2011, 12: 10-14.

[4] Journal of Huaihai Institute of Technology (Social Science Edition) Journal of Huaihai Institute of Technology (Social Science Edition) Journal of Huaihai Institute of Technology (Social Science Edition), 2011,24: 141-168 (in Chinese with English abstract) 